J. Clin. Chem. Clin. Biochem.

Vol. 24, 1986, pp. 1009-1016

(C) 1986 Walter de Gruyter \& Co. Berlin - New York

\title{
Enolase Isoenzymes as Tumour Markers
}

\author{
By K.-D. Gerbitz, J. Summer, I. Schumacher
}

Institut für Klinische Chemie und Forschergruppe Diabetes, Städt. Krankenhaus München-Schwabing

H. Arnold, A. Kraft

Medizinische Klinik I der Universität Freiburg and

K. Mross

Department of Oncology, Acad. Hospital Free University of Amsterdam

(Received May 6/July 18, 1986)

Summary: $\alpha$ - and $\gamma$-enolase isoenzyme substance concentrations were measured in serum and plasma from healthy subjects and from 174 patients with different solid tumours. While $\alpha$-enolase was found to be increased in the plasma of patients with tumours of quite different origin, $\gamma$-enolase apparently reflected malignancies of the neuroendocrine system. Before the beginning of the cytotoxic therapy $\gamma$-enolase was increased above the upper limit of the reference range $(10 \mu \mathrm{g} / \mathrm{l})$ in $27 / 27$ patients $(100 \%)$ suffering from small cell lung cancer. Most patients with squamous cell carcinoma of the lung or with prostatic cancer exhibited normal $\gamma$-enolase, while both tumour types produced high plasma substance concentrations of the $\alpha$ isoenzymes of enolase.

\section{Wertigkeit der Enolase-Isoenzyme als Tumormarker}

Zusammenfassung: Die Substanzkonzentrationen von $\alpha$ - und $\gamma$-Enolase-Isoenzym wurden im Serum und Plașma von Gesunden und 174 Patienten mit unterschiedlichen, soliden Tumoren bestimmt. Während sich die $\alpha$-Enolase-Formen als relativ unspezifisch, $d$. $h$. bei unterschiedlichen Tumoren im Plasma erhöht fanden, zeigten die $\gamma$-Isoenzyme maligne Erkrankungen des neuroendokrinen Systems relativ spezifisch an. Bei einem Kollektiv von 27 Patienten mit kleinzelligem Lungen-Karzinom fand sich vor der Therapie in $100 \%$ der Fälle ein Anstieg der $\gamma$-Ënolase über den oberen Referenzwert $(10 \mu \mathrm{g} / \mathrm{l})$. Patienten mit Plattenepithel-Karzinom der Lunge und solche mit Prostata-Karzinomen hatten in der Regel normale $\gamma$-Enolase-, dagegen erhöhte $\alpha$ Enolase-Substanzkonzentrationen im Plasma.

\section{Introduction}

Cells related to the amine precursor uptake and decarboxylation (APUD) system (1) share several common properties, which include the ability to produce and secrete peptides, the presence of storage vesicles and a similar enzyme and isoenzyme pattern. One of the marker proteins for this system is the $\gamma$-isoenzyme of enolase (neuron-specific enolase, NSE) extensively studied and characterized by Marangos' group (2). Recently it was found that small cell lung carcinoma cells also express APUD cell-specific markers such as bombesin, $L$-dopa decarboxylase and $\gamma$-enolase (3). The first report by Carney et al. (4) that $\gamma$-enolase is elevated to a high degree in the serum of most small cell lung cancer patients was confirmed by others (5-14), but it became evident that patients suffering 
from other malignancies may also exhibit increased $\gamma$-enolase in serum. Furthermore, high levels of $\alpha$ enolase were reported for some small cell lung cancer patients $(4,5)$. Therefore we investigated the specificity of $\alpha$ - and $\gamma$-enolase isoenzymes in plasma samples from a large group of patients diagnosed with different types of solid malignant tumours.

\section{Methods}

Two different assay techniques were used for the determination of enolase isoenzymes, a solid phase immuno-bioluminescence assay procedure (SIBA) recently described by our group (7) and a commercially available radioimmunological assay $(6,10)$ (NSE-RIA, Pharmacia Freiburg, Germany). For the bioluminescence test system, enolase isoenzymes were prepared from human brain as described (14). Polyclonal antisera against $\alpha$ and $\gamma$-enolases were raised in rabbits (Chinchilla bastards), purified by affinity chromatography and coated onto polystyrene tubes. Enolase catalytic activity fixed to the antibodycoated tubes was measured in a combined assay using pyruvate kinase and the luciferin-luciferase system (7). Besides the $\alpha \alpha$ and $\gamma \gamma$ isoenzymes, a dimeric hybrid form, $\alpha \gamma$, is also present in several tissues as. well as in serum or plasma, and it crossreacts to a certain extent with the respective anti $\alpha$ - or anti $\gamma$ antibodies. The respective isoenzyme catalytic activities were measured specifically as follows: for determination of $\alpha \alpha$-enolase catalytic activity samples were first incubated in tubes coated with affinity purified anti- $\gamma$ antibodies. This resulted in a total extraction of $\alpha \gamma$ - and $\gamma \gamma$-isoenzymes as demonstrated in separate experiments with the respective purified isoenzymes. The samples were then transferred to anti- $\alpha$-coated tubes and the catalytic activity measured by the combined bioluminescence system. For $\gamma \gamma$-enolase the procedure was performed vice versa. $\alpha \gamma$-Enolase catalytic activity was calculated by subtracting the sum of the specifically determined $\alpha \alpha$ - and $\gamma \gamma$-enolase catalytic activities from the total enolase activity measured in uncoated tubes. Specific catalytic activities measured in such a way were referred to as $\alpha \alpha-, \alpha \gamma$ - and $\gamma \gamma$-enolase activities or calculated substance concentrations. Since this procedure was too laborious for routine use in further studies we measured the $\alpha \alpha$ and $\alpha \gamma$ and/or the $\gamma \gamma$ - and $\alpha \gamma$-isoenzyme catalytic activities together in the respective coated tubes. In this case catalytic activities or calculated substance concentrations were given with the single symbol $\alpha$ or $\gamma$.

The bioluminescence assay measures enzyme catalytic activities. For comparison with the radioimmunological assay, which was performed in parallel, and with data in the literature, mostly obtained with specific protein determinating methods such as enzyme- or radioimmuno-assays, we had to transform the catalytic activity values into enzyme substance concentrations. Since we did not know the specific catalytic activities of the native enolase isoenzymes, i.e. in plasma, we calculated the enzyme substance concentrations on the basis of the specific catalytic activities of our purified isoenzyme preparations ( $\alpha \alpha$-enolase: $90 \mathrm{kU} / \mathrm{g}$ of protein; $\gamma \gamma$-enolase: $50 \mathrm{kU} / \mathrm{g}$ of protein). Since the $\alpha \gamma$-hybrid form was not purified to homogeneity, enzyme substance concentrations, calculated from combined measurements of $\alpha \alpha / \alpha \gamma$ - or $\gamma \gamma / \alpha \gamma$ catalytic activities, are assumed to be only approximate. The radioimmunological assay was performed according to the manufacturer's instructions (NSE, Pharmacia). Measurements were done in serum or heparinized plasma.

A correlation of $\gamma$-enolase values in 106 plasma samples obtained with both methods (SIBA and RIA) yielded $y=-4.2$ $+0.97 \mathrm{x} ; \mathrm{r}=0.884$. In $17 / 19$ plasma samples from patients with small cell lung cancer both methods revealed elevated $\gamma$ enolase and similar results. With the exception of the data in table 1 , all other figures and tables show only $\gamma$-enolase substance concentrations determined radioimmunologically by use of the Pharmacia assay (RIA), while all of the $\alpha$-enolase substance concentrations were calculated from our bioluminescence assay (SIBA).

The intra-( $n=20)$ and inter-( $n=14)$ assay coefficients of variation at cut off point concentrations were $3.4 \%$ and $8 \%$ for the RIA and $8 \%$ and $13 \%$ for the SIBA, respectively. Addition of purified $\alpha \alpha$-enolase and $\gamma \gamma$-enolase to the respective assay systems resulted in a near $100 \%$ recovery without any crossreactivity.

\section{Classification of patients}

In all patients $(n=174)$ the diagnosis of the respective solid tumours was confirmed histologically, and immunohistochemically if necessary. According to the WHO Histological Typing of Lung Tumours, the classification of small cell carcinoma includes oat cell carcinoma, intermediate cell type and combined oat cell carcinoma; squamous cell carcinoma includes as a variant the spindle cell carcinoma; adenocarcinoma consists of acinar adenocarcinoma, papillary adenocarcinoma, bronchiolo-alveolar carcinoma and solid carcinoma with mucus formation; large cell carcinoma includes giant cell carcinoma and clear cell carcinoma. When mixed type carcinomas are found, the predominate cell type determines the classification. Before the start of cytotoxic chemotherapy, 27 patients with small cell lung carcinoma were classified with respect to the extent of the disease. In 8 patients the disease was limited (tumour localized in one hemithorax and/or ipsilateral supraclavicular lymphnodes) and in 19 patients the disease was extensive. The number of clinically detected metastatic sites, confirmed by brain or abdomen scan, bone marrow biopsy, and ultrasound was recorded. Patients were treated intravenously with a combination chemotherapy consisting of adriamycin $\left(50 \mathrm{mg} / \mathrm{m}^{2}\right.$ of body surface), cyclophosphamide (1000 $\mathrm{mg} / \mathrm{m}^{2}$ of body surface) and oncovin $(2 \mathrm{mg})$ every three weeks (ACO-scheme).

Patients with limited disease received a prophylactic cranial irradiation and were randomized for chest irradiation with $0 \mathrm{~Gy}, 30 \mathrm{~Gy}$ and $50 \mathrm{~Gy}$. When progression occurred, treatment was changed to Cisplatin VP $16\left(40 \mathrm{mg} / \mathrm{m}^{2}\right.$ of body surface) for two days and etoposide $\left(100 \mathrm{mg} / \mathrm{m}^{2}\right.$ of body surface) for three days intravenously every three weeks. A complete remission was defined as a total clinical and radiological involution of the tumour.

\section{Results}

Enolase isoenzymes in serum and plasma from healthy subjects

Table 1 summarizes the values for the different isoenzymes in serum and plasma from healthy subjects. In general, values obtained either by separate determinations of the different isoenzyme $\alpha \alpha, \alpha \gamma$ and $\gamma \gamma$ (Part A) or by combined detection of $\alpha$ - or $\gamma$-isoenzymes, i.e. $\alpha \alpha / \alpha \gamma$ or $\gamma \gamma / \alpha \gamma$ (Part B), in serum are higher than those from in plasma. This holds true for both methods used (SIBA and RIA) and is consistent with data in the literature $(5,11)$. 
Tab. 1. Enolase isoenzymes in serum and plasma from healthy subjects.

\begin{tabular}{|c|c|c|c|}
\hline & $\begin{array}{l}\alpha \alpha \text {-Enolase } \\
(\mu g / l) \\
\text { SIBA } \\
(n=40)\end{array}$ & $\begin{array}{l}a \gamma \text {-Enolase } \\
(\mu g / 1) \\
\text { SIBA } \\
(n=40)\end{array}$ & $\begin{array}{l}\gamma \gamma \text {-Enolase } \\
(\mu \mathrm{g} / \mathrm{l}) \\
\text { SIBA } \\
(\mathrm{n}=40)\end{array}$ \\
\hline $\begin{array}{l}\text { A Plasma } \\
\text { mean } \pm S D \\
\text { range }\end{array}$ & $\begin{array}{r}24 \pm 10 \\
2 \leq 50\end{array}$ & $\begin{array}{l}6.0 \pm 3.2 \\
2 \pm 15\end{array}$ & $\begin{array}{l}3.3 \pm 1.5 \\
0.5-7\end{array}$ \\
\hline \multirow[t]{3}{*}{$\begin{array}{l}\text { Serum } \\
\text { mean } \\
\text { range }\end{array}$} & $\begin{array}{l}56 \pm 17 \\
20 \simeq 95\end{array}$ & $\begin{array}{r}11 \pm 4 \\
4 \leq 17\end{array}$ & $\begin{array}{l}8 \pm 2.8 \\
2 \pm 16\end{array}$ \\
\hline & $\alpha$-Enolases & \multicolumn{2}{|c|}{$\gamma$-Enolases $(\mu \mathrm{g} / 1)$} \\
\hline & $\begin{array}{l}\text { SIBA } \\
(n=40)\end{array}$ & $\begin{array}{l}\text { SIBA } \\
(n=40)\end{array}$ & $\begin{array}{l}\text { RIA } \\
(n=20)\end{array}$ \\
\hline $\begin{array}{l}\text { B } \\
\text { mean } \\
\text { range }\end{array}$ & $\begin{array}{r}28 \pm 13 \\
2 \pm 70\end{array}$ & $\begin{array}{l}7.1 \pm 2.1 \\
1 \leq 12\end{array}$ & $\begin{array}{l}4.8 \pm 1.1 \\
2-8\end{array}$ \\
\hline $\begin{array}{l}\text { Serum } \\
\text { mean } \\
\text { range }\end{array}$ & $\begin{array}{l}84 \pm 29 \\
40-150\end{array}$ & $\begin{aligned} 28 & \pm 9.3 \\
7 & -42\end{aligned}$ & $\begin{array}{c}10.9 \\
6\end{array}$ \\
\hline
\end{tabular}

Tab. 2. Cases with elevated enolase values in various tumours and diseases.

\begin{tabular}{lcc}
\hline Tumour & $\alpha$-enolases*) & $\gamma$-enolases*) \\
\hline Small cell lung carcinoma & $8 / 19$ & $65 / 75$ \\
Squamous cell carcinoma (lung) & $16 / 16$ & $2 / 16$ \\
Adeno carcinoma (lung) & $3 / 10$ & $3 / 10$ \\
Large cell carcinoma (lung) & $3 / 3$ & $1 / 3$ \\
Breast cancer & $4 / 14$ & $4 / 14$ \\
Colonic carcinoma & $0 / 8$ & $1 / 8$ \\
Carcinoma of the rectum & $1 / 6$ & $1 / 6$ \\
Prostatic carcinoma & $4 / 4$ & $0 / 4$ \\
Ewing sarcoma & $1 / 1$ & $1 / 1$ \\
Teratoma & $1 / 1$ & $1 / 1$ \\
Merkel cell sarcoma & $0 / 1$ & $1 / 1$ \\
Neuroblastoma & $1 / 1$ & $2 / 2$ \\
Gastric carcinoma & $0 / 3$ & $1 / 3$ \\
Pancreatic carcinoma & $2 / 2$ & $0 / 2$ \\
Thyroid carcinoma & $1 / 1$ & $0 / 1$ \\
Bladder carcinoma & $1 / 1$ & $0 / 1$ \\
Sarcoma of the scrotum & $0 / 1$ & $1 / 1$ \\
Oesophageal carcinoma & $1 / 1$ & $0 / 1$ \\
Laryngeal carcinoma & $1 / 2$ & $1 / 2$ \\
Lymphoma & $0 / 1$ & $0 / 1$ \\
Lymphogranuloma (Hodgkin) & $0 / 1$ & $0 / 1$ \\
Histiocytoma & $1 / 1$ & $0 / 1$ \\
Seminoma & $0 / 1$ & $0 / 1$ \\
Hypernephroma & $2 / 2$ & $0 / 2$ \\
Cholangioma & $0 / 1$ & $1 / 1$ \\
Meningioma & $1 / 1$ & $0 / 1$ \\
Schwannoma & $0 / 1$ & $0 / 1$ \\
Pheochromocytoma & $\mathrm{n} . \mathrm{d}$. & $1 / 1$ \\
Islet cell carcinoma & $\mathrm{n} . \mathrm{d}$. & $0 / 1$ \\
Nesidioblastosis & $\mathrm{n} . \mathrm{d}$. & $0 / 1$ \\
Islet cell adenoma (insulinoma) & $\mathrm{n} . \mathrm{d}$. & $0 / 10$ \\
\hline
\end{tabular}

*) Cases with elevated values/total cases; n.d. = not detected.
Enolase isoenzymes in plasma from patients suffering from different malignant tumours

Plasma samples from 174 patients with different tumours were investigated. Results for small cell lung carcinoma $(\mathrm{n}=75)$, squamous lung carcinoma $(n=16)$, adenocarcinoma of the lung $(n=10)$, large cell carcinoma $(n=3)$, breast cancer $(n=14)$, colonic carcinoma $(n=8)$, carcinoma of the rectum $(n=6)$, prostatic carcinoma $(n=4)$ and some special endocrine tumours $(n=6)$ are summarized in figure 1 . The patients listed in table 2 and figure 1 were not classified with respect to tumour degree or to stage of therapy. The cut-off point was set at 50 $\mu \mathrm{g} / \mathrm{l}$ and $10 \mu \mathrm{g} / 1$ for $\alpha$ - and $\gamma$-enolase, respectively. For all other tumours $(n=32)$, listed in table 2 , but not demonstrated in figure 1 , normal or near normal $(<20 \mu \mathrm{g} / \mathrm{l}) \gamma$-enolase concentrations were found, while in some patients $\alpha$-enolase was slightly elevated.

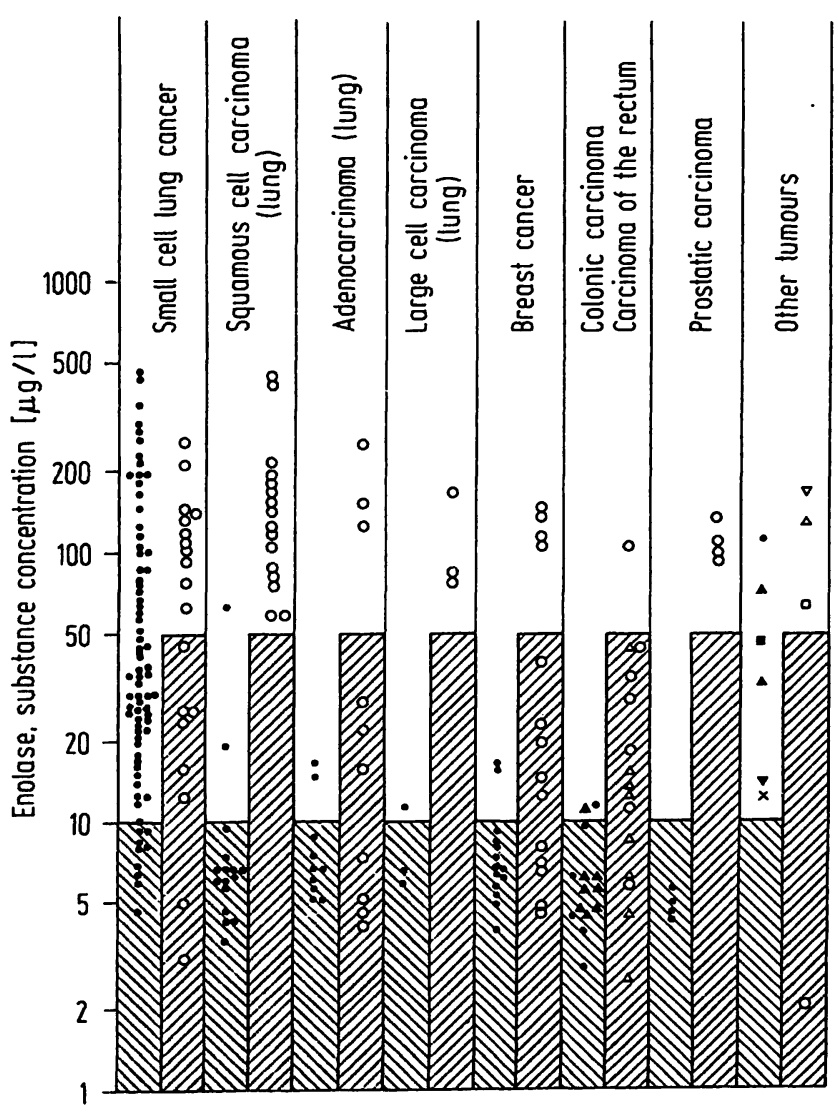

Fig. 1. $\alpha$ - and $\gamma$-enolase isoenzymes in plasma from tumour patients

The shaded area represents the reference range found in healthy subjects (tab. 1). $\alpha$-Enolase concentrations (open symbols) are calculated from bioluminescence measurements (see Methods); $\gamma$-enolase concentration (closed symbols) are determined radioimmunologically. Carcinoma of the rectum, $0, \propto$; colonic carcinoma, $\triangle$, $\Delta$; last column: neuroblastoma, $\Delta, \Delta ;$ Merkel cell sarcoma, ०, ०; Ewing sarcoma, ०, a teratoma, $\nabla, \nabla$; pheochromocytoma, $x$. 
$\gamma$-Enolase concentrations were increased in $65 / 75$ plasma samples from unselected small cell lung carcinoma patients $(87 \%)$. It should be noted, however, that all of the 10 patients with normal $\gamma$-enolase concentrations were under cytotoxic therapy. $\alpha$-Enolase was measured in 19 of the small cell lung carcinoma patients and increased values were found in 11 of $19(58 \%)$. Patients with other types of malignant lung tumours in general exhibited normal or only slightly increased $\gamma$-enolase concentrations. Thus $2 / 16$ $(13 \%)$ patients with squamous carcinomas, $2 / 10$ $(20 \%)$ with adenocarcinomas and $1 / 3$ with large cell carcinomas had elevated plasma $\gamma$-enolase.

High levels of $\alpha$-enolase, however, were found in all $(16 / 16)$ plasma samples from patients with squamous cell carcinoma and in all (3/3) large cell carcinoma patients, but only in 3 out of $10(30 \%)$ with adenocarcinoma.

Two of the fourteen patients with breast cancer had slightly increased $\gamma$-enolase in plasma, while in $4 / 14$ $\alpha$-enolase was found above the reference range. Two of the fourteen patients with colonic cancer or carcinoma of the rectum had slightly elevated $\gamma$-enolase, while in all of these patients $\alpha$-enolase in plasma was found within the reference range. The four patients with prostatic cancer exhibited a different pattern, i. e. normal $\gamma$-enolase and elevated $\alpha$-enolase in plasma. In the last column of figure 1 , the enolase values for six patients with different malignancies are shown, i.e. two cases of neuroblastoma, one Ewing sarcoma, one Merkel cell sarcoma, one pheochromocytoma and one teratoma. Patients with islet cell carcinoma (1 case), nesidioblastosis (1 case) or insulinoma (10 adenomas) exhibited normal $\gamma$-enolase levels (tab. 2 , data not shown in fig. 1).

Figure 2 shows the correlation between $\alpha$ - and $\gamma$ enolase concentrations in plasma from patients with squamous cell carcinoma $(\mathrm{n}=16)$ and small cell lung carcinoma $(n=19)$. Fourteen out of sixteen patients with squamous cell carcinoma exhibited elevated $\alpha$ enolase, but $\gamma$-enolase was normal, indicating that there was also no increase in $\alpha \gamma$-enolase. Four out of nineteen patients with small cell lung carcinoma had high $\gamma$-enolase, but normal $\alpha$-enolase, while in plasma from most of the small cell lung carcinoma patients $(13 / 19)$ high levels of $\alpha$ - as well as $\gamma$-isoenzymes were found.

Twentyseven patients out of the whole group of small cell lung carcinoma patients $(n=75)$ were classified with respect to the tumour degree before beginning of the cytotoxic therapy. Eight were in a limited stage of disease, 19 in an advanced stage of disease. $\gamma$ Enolase values obtained in both groups before ther-

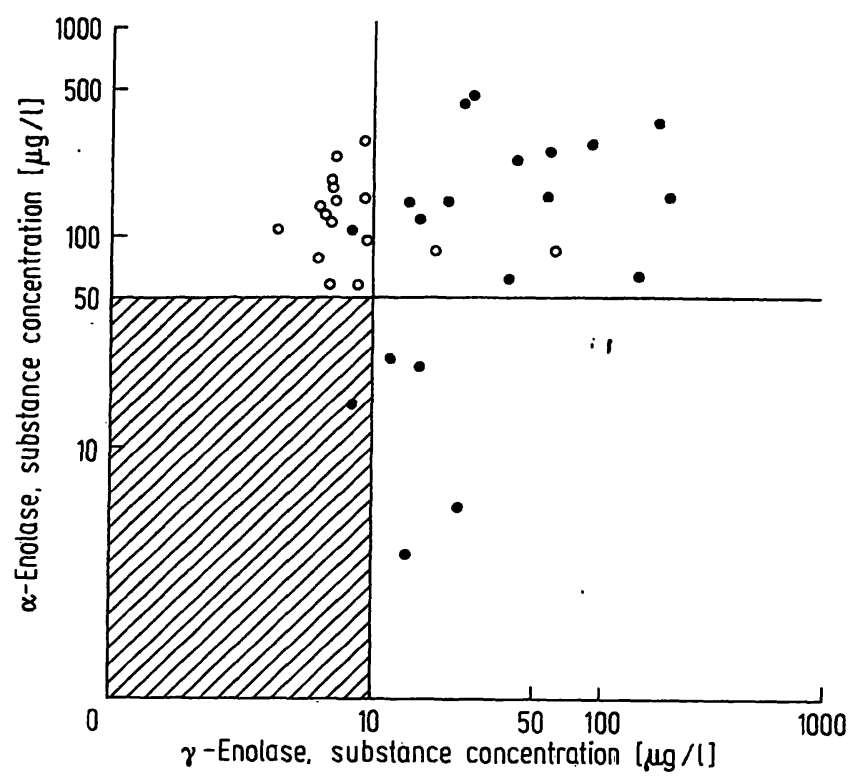

Fig. 2. Comparison of $\alpha$ - and $\gamma$-enolase isoenzymes in plasma from patients with small cell lung carcinoma $(\bullet, \mathbf{n}=19)$ or squamous cell carcinoma $(0, n=16)$.

$\alpha$-Enolase concentrations are calculated from bioluminescence measurements (see Methods); $\gamma$-enolase concentrations are determined radioimmunologically. Patients with small cell lung carcinoma were not selected with respect to disease extent. The shaded area gives the reference range found in healthy subjects (tab. 1).

apy were statistically different: limited disease, mean: $40 \mu \mathrm{g} / \mathrm{l}$, range: $28-66 \mu \mathrm{g} / \mathrm{l}$; extensive disease, mean: $187 \mu \mathrm{g} / \mathrm{l}$, range: $14-446 \mu \mathrm{g} / \mathrm{l} ; \mathrm{p}<0.001$ (Student's ttest). All of these 27 patients had increased $\gamma$-enolase values in plasma at the beginning of therapy. In the plasma of 6 patients with limited disease and 7 patients with extensive disease, measurements of $\gamma$ enolase were performed during extensive chemotherapy over a period from 3 to 20 weeks (fig. 3). In 5 patients with limited disease, $\gamma$-enolase values declined in accordance with the clinical criteria of remission, while one patient changes from a limited to an extensive diseased stage. In $5 / 7$ patients with extensive disease the transient response to therapy was accompanied by a fall of $\gamma$-enolase concentrations in plasma, while in two non-responders $\gamma$-enolase increased.

\section{Discussion}

The search for and research on proteins specific for definite cells or tissue types has been intensified during recent years. The basis for this approach is the concept that the differentiated functions of specialized cells may be expressed by means of the properties of the individual proteins. 

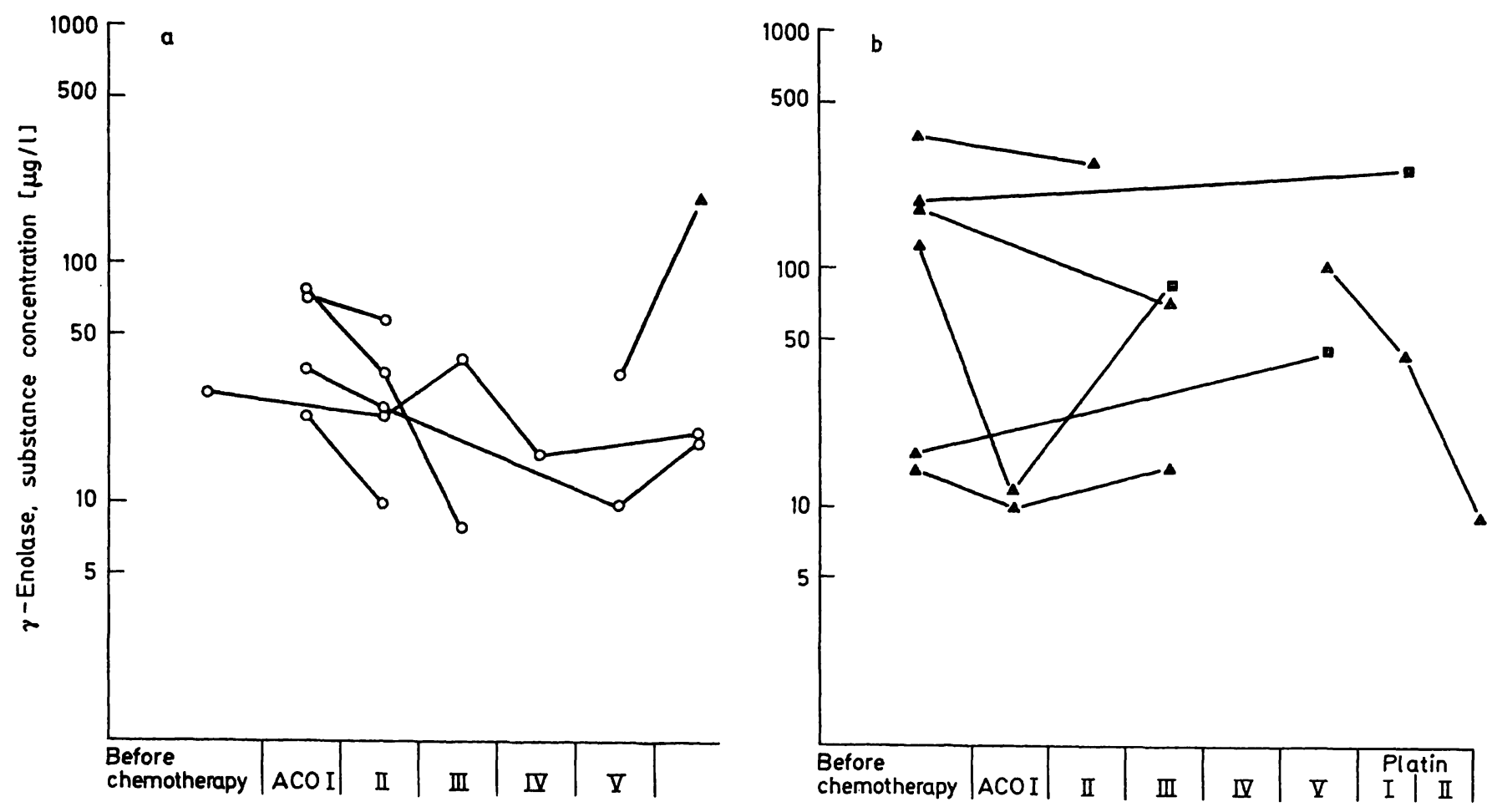

Fig. 3. Sequential plasma $\gamma$-enolase determinations in small cell lung cancer patients with limited disease (a) and extensive disease (b)

a) limited disease: patients during remission, $૦-\circ$; patient in tumour progression from limited to extensive disease, $0-\mathbf{A}$

b) extensive disease: patients during response to therapy, $\Delta-\Delta$; patients after relapse and tumour progression, $\Delta-\mathbf{a}$; for details of the chemotherapy see the method section: $\mathrm{ACO}=$ adriamycin/cyclophosphamide/oncovin.

Therefore fresh attention has been paid to specific isoenzyme patterns. The dimeric glycolytic enzyme, enolase, consists of three distinct subunits $\alpha, \beta$, and $\gamma$ and the respective hybrid forms (2). While the $\beta$ subunit as a part of $\beta \beta$-isoenzyme or the $\alpha \beta$-hybrid seems to be relatively muscle-specific (15), the $\alpha$ subunit in its different forms is widely distributed in mammalian tissues (16). The $\gamma \gamma$-isoenzyme has been identified with the 14-3-2 nervous system-specific protein $(16,17)$ and the two isoenzyme forms, $\alpha \gamma$ and $\gamma \gamma$, have been immunohistochemically localized in neurons (19), neuroendocrine cells (19) as well as in most bloọd cells $(11,20)$. The term neuron-specific enolase (NSE) is therefore misleading. Furthermore, some confusion exists in the literature, because certain authors use the name neuron-specific enolase only for the homologous dimeric isoenzyme $\gamma \gamma$-enolase, while others describe both $\alpha \gamma$ and $\gamma \gamma$-enolase by this term. Since the tissue distribution of the $\alpha \gamma$ hybrid is not exactly known, and most of the polyclonal $\gamma$-antisera used for immunochemical detection cross-react with both $\gamma$-forms, we prefer the classification by Greek letters. Consequently we use the description of a dimeric enzyme, i. e. $\alpha \alpha, \alpha \gamma$ or $\gamma \gamma$, if the isoenzymes are determined separately, while the subunit specification is used for combined measurements of the respective subunits.
As demonstrated in table 1 enolase isoenzyme levels are considerably higher in serum than in plasma. This is true for all isoenzymes, irrespective whether the isoenzymes are determined separately or by combined measurements of the different subunit forms. Since platelets contain high amounts of $\alpha \alpha, \alpha \gamma$ and $\gamma \gamma$ isoenzymes $(11,21)$, specific enzyme proteins might be released from aggregated thrombocytes during clotting, thereby resulting in higher serum levels. We therefore prefer measurements in plasma instead of serum. Due to the enolase content of red blood cells, even slight haemolysis contributes to a significant increase in plasma or serum levels, especially of the $\alpha$-enolase forms, as shown by Day \& Thompson (21).

The bioluminescence assay (SIBA) measures enzyme catalytic activities. Substance concentrations calculated on the basis of our purified isoenzyme preparations (9) are in fairly good agreement with data reported in the literature and obtained with enzyme protein determination methods. Thus Kato et al. (11) reported $20 \pm 6,4.1 \pm 1.4$ and $1.5 \pm 0.4 \mu \mathrm{g} / \mathrm{l}$ for $\alpha \alpha-, \alpha \gamma$ - and $\gamma \gamma$-enolase, respectively, in plasma and $59 \pm 27,8.0 \pm 3.1$ and $2.0 \pm 0.9 \mu \mathrm{g} / \mathrm{l}$ in serum. Other authors $(4-6)$ found values between 1 and $7 \mu \mathrm{g} / \mathrm{l}$ for the $\gamma$-enolases in plasma and somewhat higher values in serum (tab. 3). This distribution 
Tab. 3. Frequency of raised $\gamma$-enolase levels in lung tumour patients before treatment.

\begin{tabular}{|c|c|c|c|c|c|}
\hline \multirow[t]{2}{*}{ Author (ref.) } & \multirow{2}{*}{$\begin{array}{l}\text { Upper limit of } \\
\text { reference range } \\
(\mu \mathrm{g} / \mathrm{l})\end{array}$} & \multicolumn{3}{|c|}{ Small cell lung cancer $(\%)$} & \multirow{2}{*}{$\begin{array}{l}\text { Non small cell } \\
\text { lung cancer } \\
(\%)\end{array}$} \\
\hline & & limited & extensive & all cases & \\
\hline Carney' et al. (4) & 12 & $15 / 38 \quad(39)$ & $49 / 56 \quad(87)$ & $63 / 94$ & - \\
\hline Arịoshi et al. (5) & 7.5 & - & - & $12 / 20$ & $6 / 54$ (11) \\
\hline Kato et al. (11) & $\sim 14$ & - & - & $8 / 9$ & - \\
\hline Aroney et al. (8) & 12 & - & - & $7 / 7 \quad(100)$ & . 2/2(100) \\
\hline Johnson et al. (9) & 20 & $23 / 39 \quad(59)$ & $45 / 54 \quad(83)$ & $68 / 93 \quad(73)$ & - \\
\hline Esscher et al. (12) & 12 & $34 / 48 \quad(72)$ & $54 / 55(98)$ & $88 / 103$ (85) & $13 / 51 \quad(27)$ \\
\hline Akoun et al. (13) & 10 & $6 / 16 \quad(38)$ & $22 / 27 \quad(79)$ & $28 / 43 \quad(65)$ & $2 / 14$ (14) \\
\hline Cooper et al. (10) & 13.5 & $25 / 38 \quad(66)$ & $34 / 39$ (87) & $59 / 77 \quad(77)$ & $16 / 94$ (17) \\
\hline Pählman et al. (6) & 13 & $33 / 47 \quad(70)$ & $56 / 58 \quad(97)$ & $89 / 105(85)$ & $8 / 41 \quad(20)$ \\
\hline This study & 10 & $8 / 8(100)$ & $19 / 19(100)$ & $27 / 27 \quad(100)$ & $5 / 29 \quad(17)$ \\
\hline
\end{tabular}

pattern of the enolase isoenzymes is only valid for healthy subjects and can be altered dramatically in serum or plasma samples from tumour patients, as shown by Kato et al. (15) and our group (14).

$\gamma$-Enolase isoenzymes have also been detected immunohistochemically' in neuroendocrine tumours (22, $23)$, as well as in carcinomas of the lung $(3,24,25)$. Carney and coworkers were the first (4) to use the determination of $\gamma$-enolases as a marker for assessing the extent of the disease, and response to therapy of small cell lung cancer. In the meantime several reports have confirmed their results $(5-14)$. However it became evident that patients with small cell lung carcinoma as well as patients with non-small cell lung carcinoma may exhibit high concentrations of $\gamma$-enolase in plasma or serum $(3-8,10)$. These results, confirmed by our measurements, possibly reflect some uncertainties in the exact histological classification, caused by mixed type carcinomas $(24-26)$. Alternatively, during tumour progression, non small cell lung cancers cells could also develop the ability to produce $\gamma$-enolase isoenzymes as a result of de-differentiation processes. In this connection, it is interesting that Schmechel et al. (27) reported a switch from nonneuronal to neuronal enolase during development of neurons.

About one half of the small cell lung cancer patients also exhibited high levels of $\alpha$-enolase in plasma. Separate determinations of the isoenzymes $\alpha \alpha$ and $\alpha \gamma$ (14) showed, in most cases, elevations of both isoenzymes. Patients suffering from squamous cell carcinoma or large cell carcinoma had increased levels of $\alpha$-enolase in plasma, while raised levels of $\gamma$-enolase were found only in a small percentage. Further studies are required to clarify the question of whether measurements of $\alpha$ - and $\gamma$-isoenzymes in plasma are clinically relevant for the diagnosis of different types of lung cancer.
When stage of disease and therapy were not taken into consideration, $87 \%$ of the small cell lung carcinoma patients had elevated $\gamma$-enolase substance concentrations in plasma. However, all of the 10 patients exhibiting normal $\gamma$-enolase values in plasma were under therapy. In 27 patients out of the whole small cell lung carcinoma collective we were able to measure $\gamma$-enolase in plasma before the beginning of the therapy. The increase in $\gamma$-enolase was dependent on the stage of disease before therapy, but all of these patients exhibited $\gamma$-enolase values in plasma above the upper level of the reference range. Thus the sensitivity of $\gamma$-enolase as a marker for small cell lung carcinoma approaches $100 \%$. The fact that our data on sensitivity are even higher than those reported in the literature $(3-13$, tab. 3$)$ might be partially explained by the relatively low cut-off point $(10 \mu \mathrm{g} / \mathrm{l})$ used in our study, as well as by the use of plasma instead of serum. Serial determinations of $\gamma$-enolase in plasma samples from some patients receiving cytotoxic therapy for small cell lung carcinoma showed a correlation between the initial clinical response and the $\gamma$-enolase levels. This was true for patients who responded to therapy, and the reverse was true for non-responders. Progression of the disease, as well as emergence of therapeutic resistance, was usually accompanied by an increase of $\gamma$-enolase values. However, in two of our small cell lung carcinoma patients $\gamma$-enolase normalized during the remission period and remained within the reference range, although these two patients died soon after from progressive disease. Both patients had been typed as small cell lung carcinoma by histology after bronchial biopsy. Post mortem histology, however, revealed a change of the tumour type, in one case a large cell carcinoma, in the other case a carcinoid. Possibly both cases reflected the phenomenon that the usual emergence of resistance to cytotoxic therapy seems to be accompanied by transition of small cell lung 
carcinoma to other cellular phenotypes $(28,29)$. Interestingly, Minna's group $(30,31)$ recently reported that the loss of endocrine characteristics from small cell lung carcinoma cells maintained in cell culture was paralleled by a $20-80$ fold amplification of oncogenes of the myc-family.

Among the 31 different types of solid tumours investigated in this study only those listed in figure 1 showed varying degrees of elevation of $\gamma$-enolase in plasma, while slightly raised plasma $\alpha$-enolase values were sometimes found in other tumours. Four cases with prostatic cancer had $\gamma$-enolase levels within the reference range, but they showed increased $\alpha$-enolase. This result needs further confirmation. Two cases with neuroblastoma and one with a pheochromocytoma showed elevated plasma $\gamma$-enolase levels, consistent with reports in the literature $(6,33,34)$. The high levels of $\gamma$-enolase found in the single cases suffering from Merkel cell sarcoma or teratoma might be explained by the fact that these tumours also belong to the endocrine system (35). Malignant and benign tumours of the islets of Langerhans generally did not lead to an increase of $\gamma$-enolase in plasma.

\section{References}

1. Pearse, A. G. E. (1968) Proc. R. Soc. Biol. 170, 71-80.

2. Marangos, P. J., Zis, A. P., Clark, R. L. \& Goodwin, F. K. (1978) Brain Res. 150, 117-133.

3. Carney, D. N., Broder, L., Edelstein, M., Gazdar, A. F., Hansen, M., Havemann, K., Matthews, M. J., Sorenson, G. D. \& Videløv, L. (1983) Cancer Treat. Rep. 67, 27-35.

4. Carney, D. N., Marangos, P. J., Ihde, D. C., Bunn, P. A., Cohen, M. H., Minna, J. D. \& Gazdar, A. F. (1982) Lancet I, $583-585$.

5. Ariyoshi, Y., Kato, K., Ishiguro, J., Ota, K., Sato, T. \& Suchi, T. (1983) Gann 74, 219-225.

6. Pählman, S., Esscher, T., Bergh, J., Steinholtz, L., Nou, E. \& Nilsson, K. (1984) Tumour Biology 5, 119-126.

7. Gerbitz, K.-D., Deufel, T., Summer, J., Thallemer, J. \& Wieland, O. H. (1983) Clin. Chim. Acta 133, 233-239.

8. Aroney, R. S., Dermody, W. C., Aldenderfer, P., Parsons, P., McNitt, K., Marangos, P. J., Whitacre, M. Y., Ruddon, R. W., Wiernik, P. H. \& Aisner, J. (1984) Cancer Treat. Rep. 68, 859-866.

9. Johnson, D. H., Marangos, P. J., Forbes, J. T., Hainsworth, I. D., van Welch, R., Hande, K. R. \& Greco, F. A. (1984) Cancer Res. 44, 5409-5414.

10. Cooper, E. H., Splinter, T. A. W., Brown, D. A., Muers, M. F., Peake, M. D. \& Pearson, S. L. (1985) Br. J. Cancer $52,333-338$.

11. Kato, K., Asai, R., Shimizu, A., Suzuki, F. \& Ariyoshi, Y. (1983) Clin. Chim. Acta 127, 353-363.

12. Esscher, T., Steinholtz, L., Bergh, I., Nou, E., Nilsen, K. \& Pählman, S. (1985) Thorax 40, 85-91.

13. Akoun, G. M., Scarna, H. M., Milleron, B. J., Benichon, M. P. \& Herman, D. P. (1985) Chest 87, 39-44.

14. Gerbitz, K.-D., Summer, J. \& Thallemer, J. (1984) Clin. Chem. 30, 382-386.

15. Kato, K., Okagawa, Y., Suzuki, F., Shimizu, A., Mokuo, K. \& Takahashi, Y. (1983) Clin. Chim. Acta 135, 253263.

\section{Conclusion}

In conclusion, elevated $\alpha$-enolase isoenzyme were found in the plasma of patients suffering from different solid tumours. Obviously $\alpha$-enolase isoenzymes can only be considered as unspecific tumour markers. $\gamma$-Enolase, however, can serve as a relatively specific neuroendocrine tumour marker, especially with respect to small cell lung cancer. In this connection we confirm that the commercially available radioimmunological assay for $\gamma$-enolases, used in this study, is rapid, precise and accurate. Detailed studies in close co-operation between pathologists, clinical chemists and physicians seem to be necessary to clarify the question of whether separate determinations of $\alpha$ and $\gamma$-enolases in plasma could be helpful in the differentiation of the various forms of lung cancers. Such studies are now in progress in our laboratory.

\section{Acknowledgement}

This work was supported in part by the Stiftung Deutsche Krebshilfe (W 26/84/Ge 1) and by the Bundesministerium für Forschung und Technologie (BMFT 01 ZPO11).

16. Marangos, P. J., Schmechel, D., Parma, A. M., Clark, R. L. \& Goodwin, F. K. (1979) J. Neurochem. 33, 319-329.

17. Brown, K. W., Kynoch, P. A. M. \& Thompson, R. J. (1980) Clin. Chim. Acta 101, 257-264.

18. Hullin, D. A., Brown, K., Kynoch, P. A. M., Smith, C. \& Thompson, R. J. (1980) Biochim. Biophys. Acta 628, 98108.

19. Schmechel, D., Marangos, P. J., Zis, A. P., Brightman, M. \& Goodwin, F. K. (1978) Science 199, 313-315.

20. Schmechel, D., Marangos, P. J. \& Brightman, M. (1978) Nature 276, 834-836.

21. Day, I. N. M. \& Thompson, R. J. (1984) Clin. Chim. Acta $136,219-228$.

22. Tapia, F. J., Pollack, J. M., Barbosa, A. J. A., Bloom, S. R., Marangos, P. J., Desmody, C. \& Pearse, A. G. E. (1981) Lancet $I, 808-811$.

23. Nathrath, W. B. J. \& Remberger, K. (1986) Virchows Arch. (Pathol. Anat.) 408, 421-434.

24. Marangos, R. J., Gazdar, A. F. \& Carney, D. N. (1982) Cancer Lett. 15, 67-71.

25. Dhillon, A. P., Rode, J., Dhillon, D. P., Moss, E., Thompson, R. J., Spiro, S. G. \& Corrin, B. (1985) Br. J. Cancer $51,645-652$.

26. Goodwin, G., Shaper, J. H., Abeloff, M. D., Mendelsohn, G. \& Baylin, S. B. (1983) Proc. Natl. Acad. Sci. USA 80, 3807-3811.

27. Schmechel, D. E., Brightman, M. W. \& Marangos, P. J. (1980) Brain Res. 190, 195-199.

28. Abeloff, M. D. \& Eggleston, J. C. (1981) In: Small Cell Lung Cancer, pp. 235-259 (Greco, F. A., Oldham, R. K. \& Bunn, P. A., eds.) Grune and Stratton, New York.

29. Baylin, S. B. (1985) In: Peptide Hormones as Mediators in Immunology and Oncology (Hesch, R. D., ed.) Serono Symposia Vol. 19, pp. 1-12, Raven Press, New York.

30. Little, C. D., Nau, M. M., Carney, D. N., Gazdar, A. F. \& Minna, J. D. (1983) Nature 306, 194-196. 
31. Nau, M. M., Brooks, B. J., Battey, J., Sausville; E., Gazdar, A. F., Kirsch. J. R., McBride, O. W., Bertnes, V., Hollis, G. \& Minna, J. D. (1985) Nature 318, 69-73.

32. Zeltzer, P. M., Marangos, P. J., Sather, H., Evans, A., Siegel, S., Wong, K. Y., Dalton, A., Seeger, R. \& Hammond, D. (1985) Advances Neuroblastoma Res., pp. 319329, Alan R. Liss, Inc.
33. Marangos, P. J. (1985) Advances Neuroblastoma Res., pp. 285-294, Alan R. Liss, Inc.

34. Beemer, F. A., Vlug, A. M. C., van Veelen, C. W. M., Rijksen, G. \& Staal, G. E. J. (1984) Cancer 54, 293-296.

35. Brodner, O. G., Grube, D., Helmstaedter, V., Kreienbrink, M. E., Wurster, K. \& Forssmann, W. G. (1980) Virchows Arch. (Pathol. Anat.) 388, 251-262.

Priv.-Doz. Dr. Klaus-D. Gerbiţ̦ Institut für Klinische Chemie

Städt. Krankenhaus München-Schwabing

Kölner Platz 1

D-8000 München 40 